\title{
Teaching Students about Congress and Civic Engagement
}

\author{
B. Welling Hall, Earlham College, 20o9-1o Congressional Fellow
}

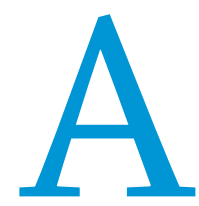

s a tenured, full professor in an endowed peace studies chair at my home institution, I chose to spend my 2009-10 sabbatical year as an American Political Science Association Congressional Fellow. Why? As I saw it, my colleagues who teach chemistry need to work with electron spectrometers; my colleagues who teach ethnomusicology need to perform with Javanese gamelans. In an analogous way, I believed that my own work with Congress would energize and refocus my research and teaching. All subfields of intellectual inquiry have their blind spots, and within the subfield of peace studies the largest blind spot may be the perspective that I thought might be gained from being a foreign policy insider. Again and again, my courses began and ended with students asking me to explain how or why the United States behaved and behaves in ways that baffle the rest of the world. I found myself saying something about "political will" and believed that if I were to answer that question in a way that felt remotely satisfying, I needed to spend some time on the ground observing how the "sausage" was made.

I ended up spending the bulk of the sabbatical year, December 2009 through August 2010, working in the office of Congressman Keith Ellison (D-MN). The year was busy meeting with constituents, drafting legislation, briefing my legislative director and the Congressman, writing speeches and talking points, and staffing Mr. Ellison in hearings and in meetings with Administration officials. It was a profoundly moving year both in terms of witnessing the difference that devoted public servants can make in attempting to craft good public policy and also in observing the gulf between the real work that needs to be done and the partisanship that divides the legislature, not to mention the protestors lining Pennsylvania Avenue.

The demographics of most congressional offices was also particularly striking. Although Americanists might know in their bones that congressional staffers are, for the most part, very young-many of them fresh out of college, it was a wake up call for me. I returned to campus motivated to confront the cynicism that keeps many of my very best students aloof from the political process. In terms of "making the sausage," I was energized to help my students address questions about the difference that an individual member of Congress can make, and, most important of all, get a crop of students, who regularly thought about NGO work but rarely thought about political work, to develop portfolios that I hoped would get them in line for choice internships and entrylevel jobs on Capitol Hill. If I learned anything during my too brief stint as a congressional staffer, it was that first-hand experience with any aspect of the Hill process translates into increased political power. That is, knowledge is power, or if not power, at least a marketable commodity for a college graduate who professes an interest in civic engagement.

\section{CIVIC ENGAGEMENT MEETS CYNICISM}

All of this learning is for naught if the audience just does not care. As a political scientist, I know that many of my colleagues have been cynical about civic engagement, settling into the critique of public policy rather than encouraging students to take on the difficult daily work. Working alongside such cynicism is probably the hardest thing I do as a teacher, and it has become even more difficult since my sojourn on Capitol Hill. I have wondered, is it possible to be cynical and to teach about active civic engagement at the same time? I think not. Why? Because to engage in civic life is to act as if commitments to community, justice, and the public good are real and achievable goals, not merely rhetorical devices. To encourage commitment to civic engagement means to believe that "the moral arc of the universe is long, but it bends toward justice" (See Block 2010). In contrast, to be cynical is to act as if any assertion of acting in the public interest is only a play for power. To be cynical means that whole-hearted commitment to civic engagement is pointless. To be cynical means to attend to the needs and desires of the self, rather than to the public good. To be cynical is to reject the very possibility of what Martin Luther King, Jr. called "the beloved community" in his injunctions to Congress as an institution (King 1989). Call me a starry-eyed idealist, if you will, but a politics that is only about power is not a politics that promotes civic engagement.

Even so, both personal experience and a review of the literature indicates that contempt for the institution of Congress is at an all time high (Pew Research Center 2009). Cynicism and apathy about politics and civic engagement is widespread not only among the general public but among college students (Longo and Meyer 2006). The recent surge in volunteering among college students has occurred alongside a decline in political participation. This is completely consistent with my own experience of students who talk about wanting to work on issues of food security, or homelessness, or environmental sustainability, but few students have conceived of this work as work that will occur in the nonprofit or private sector. They see themselves as change agents and social entrepreneurs ("What is a Social Entrepreneur?" 2011), but find it inconceivable that they might accomplish these goals through government service. My course about how to be effective congressional staffers was as much about finding ways to show students how their dreams might have legs as it was about the work of Congress itself. I aspired to close a gap noted by MacDonald (forthcoming), who commented at the 2011 APSA Teaching and Learning Conference that " $[\mathrm{t}]$ here is too little discussion of how we go about integrating internships, service, and study abroad with classroom learning. Many authors seem to suggest that such integration is simple and easy to accomplish."

How could I translate the allure and the dynamism of life in a congressional office in Washington, DC into a classroom 
Table 1

\section{PROJECT PERICLES GOALS (LIAZOS AND LISS 2009)}

Novel Approaches to Research Papers and Projects: Enabling Students to Relate Their Coursework to Real World Problems and

Exercises that Enable Students to Empathize with Individuals Increasing Student Accountability Working for Social and Political Change

\section{MY CIVIC ENGAGEMENT COURSE}

Teaching Students How to Be Congressional Staffers

(1) Schedule

(2) Letters from Constituents (with Sociology Class)

(3) Mock Hearing (with Policy class)

(4) Decision Memo with Walk and Talk

Opportunities for Private and Public Reflection that Connect

Coursework with Civic Engagement Experiences

Attending Town Halls

Travel to DC

Lobbying Experience

Collaborative and Student-Led Projects that Help Students Learn to Work with Diverse Opinions and Groups

Diverse political orientation visiting member of Congress together, what would our message be?

Exposing Students to Differing Opinions and Approaches to Help Them View Issues from Multiple Perspectives and Relate Coursework to Multiple Contexts
Tracking different members of Congress, Visit to DC, developing portfolios experience for students from several states and other countries, including Nicaragua, Iraq, and Afghanistan? The stroke of good fortune that followed immediately on the heels of these questions was that my institution, Earlham College, had recently signed on to Project Pericles. Project Pericles is a consortium of more than two dozen colleges and universities that work collaboratively on the development of civic engagement programs for colleagues, students, and communities. Periclean faculty leaders teach courses that address the civic engagement goals outlined in table 1. Teaching a course about what I had recently learned as a participant observer in a congressional office was a logical step (see Gillespie and Michelson, 2011).

\section{BRINGING CONGRESS TO THE CLASSROOM}

The most important decision I made was to focus on teaching students to be congressional staffers rather than members of Congress themselves. Why is this so important? Simulations have an august record in political science teaching. Roger H. Davidson, Dean E. Mann, and Eric R. A. N. Smith have run SIMCONG, an elaborate, extended simulation of the House of Representatives for more than 30 years (Smith 2001). Elizabeth Smith and Mark Boyer (1996) were pioneers in writing about the impact that successful classroom simulations have on active learning in political science. Former Congressman Lee Hamilton and the Center on Congress at Indiana University (2007) do path breaking work in bringing a Virtual Congress into high school classrooms. Tracks of APSA Teaching and Learning conferences have been devoted to games and simulations over several years (see "2011 APSA Teaching and Learning Conference Track Summaries").

I have directed a Model United Nations (UN) program for nearly two decades. I find that Model UN is useful in teaching empathy and moral imagination. The innovation in my congressional staff course was for students to focus on work that went on behind the scenes. I was asking them to imagine what they might be doing in a few months or years and providing some training to do it. This was, for me (and the students) very different than asking them to step into persona of a congressman or diplomatsomeone who had years of work and life experience that an 18 to 22 year old could not fully apprehend and (in my experience) could only simulate through caricature. I found myself in the truly delightful position of teaching students what I had just been taught myself (I can just imagine my legislative director singing, "She'll try to teach the things I taught her!") An unexpected benefit of the Fellowship was that I discovered all over again what it was like to be a student, with the added perspective and advantage of 25 years teaching experience. ("Jeez, I wish he would write the instructions down-I can't get it all by hearing it only once." "Feedback that I get two weeks after I've written the memo is pretty useless," and so on.)

The civic engagement course idea also got a boost from some insights that I got from occasional micro-teaching that I did as I met with constituents. "There are lots of things you would like the Congressman to attend to? He can be more responsive if you have a single Ask." "If you would like us to introduce such a bill, it would be very helpful if you had some sample language prepared." "The Congressman was actually an original cosponsor of that resolution." "Your friend decided to practice civil disobedience and doesn't like the conditions in his prison cell? Let's talk about The Night Thoreau Spent in Jail."

How exactly did I translate the daily work of a congressional staffer to the classroom? Inspired by some of the lessons that Charlie Stevenson at Johns Hopkins School of Advanced International Studies provided during an orientation seminar, I organized the class schedule so that students would do public policy writing in teams ("just like the real world") (see Pennock 2011). The course met twice a week for a 15-week semester in 90-minute sessions. (See syllabus in appendix I.) My goal, successfully realized during the course, was that students would complete staff assignments within the time frame of a 90-minute period. Rather than assigning a "coffee table" book, we discussed a manual written by former staffers for the Congressional Institute on the specific challenges of being a Hill staffer (Strand et al. 2008). This helped to bring students into the mindset of a Washington, DC internship even though we were sitting in class in Richmond, Indiana. During an introductory week, in which college librarians provided some basic bibliographic instruction on researching the biographies of individual congressional members, students compiled brief dossiers on members who they would be following/ "working for" over the course of the semester. Working largely from CQ’s Politics in America (Bicknell and Meyers 2011), we talked 
about the different personalities and appetites of individual members and the difference that these make. These discussions reflected my own recent insight that politics is based far more profoundly on effective personal relationships than I had, as an international relations specialist and policy wonk, ever seriously entertained. Thinking about politicians as "bosses" was key to getting most of the assignments in the course to work. Not unlike other simulations, a key learning goal for students was to come to an appreciation of seeing issues and events as other people would see them. In final course evaluations students reported that one of the most difficult aspects of the course was learning to write in someone else's voice for a purpose other than one's own choosing. ("Touché," I thought, "that was exactly my own experience as a new staffer.")

Our next group writing assignment was to try out the work of a congressional scheduler because this is, as I told my students, both an entry level job in a congressional office and a critical job that serves the ultimate gate-keeping function. I gave students a list of suggested meetings as shown in appendix I and a group time limit of go minutes to complete the task. The experience of trying to schedule meetings directly opposite each other, imagining the difficulty of being in two hearings and a press conference at the same time, and balancing a fundraising event with a daughter's dance recital, provided insight to crosscutting pressures that lasted all semester. All students commented on the significance of this exercise in their final course evaluations, for example:

I learned many lessons from this project but the one that stands out is LIFE IS VERY BUSY FOR A MEMBER OF CONGRESS (and transitively their staff members). I was shocked to see all of the mock events, meetings, tasks, etc. that we had to fit into a single week and then double shocked when I was informed that this was a light load and that normally time slots would be doubly or triply booked. This task showed me a very important aspect of the daily work of a congressional office, namely the constant events and such that you have to prepare your member for and help arrange or organize (depending on your role). I learned about what a general congressperson's schedule would look like with voting sessions/floor time Tuesday through Thursday and district time Thursday through Sunday as well as what other commitments a member might be engaged in and the priorities of those engagements/tasks (Hall 2011).

Because a significant focus of those meetings (at least in the office I worked in) is constituent work, another exercise we attempted collectively was responding to constituent mail. My students learned that the average congressional office receives something like 4,0oo communications each week. Interns and entry-level staffers have the first contact with those messages as they come into the office. I thought that a well-crafted letter to a constituent would be a good writing sample for a student to have in a job search portfolio. As I was thinking about this exercise and talking about it at Earlham, I learned that my colleague in the sociology department, Steve Butler, had students in his course about institutions and inequality write letters about financial aid to members of Congress. Voilà, a collaborative assignment was born! Steve Butler's students wrote their letters, mailed them off, and sent a copy along to me. My students researched the member's position on the issues and wrote letters back-not just to an individual "constituent," but a letter that would respond to the concerns raised by all of the sociology class students, since my students now knew that the time constraints in an office were such that individual letters to constituent concerns on public policy issues just do not happen.
Because briefing members on public policy issues and the preparation of briefing books is another key task of a staffer, I had initially conceived of the class putting together a briefing book on a policy issue as an exercise in and of itself. I wanted students to get an idea of the work that goes into preparing a member of Congress to give an opening one-minute statement on a controversial issue and preparing questions for witnesses. As it turned out, another colleague, Thor Hogan in the politics department, was teaching a course on energy policy and we were able to time the assignments so that his students were prepared to provide witness testimony at a mock hearing while my students prepared to drill the witnesses on topics they knew very little about (not unlike Congress). While the mock hearing itself satisfied the participants, even more learning occurred during the preparation phase when the witnesses realized that they wanted to know what questions they were going to be asked and my students realized that they did not want to ask questions that made them look uninformed on TV. (We simulated the presence of C-SPAN at the hearing by having a student worker from the library videotape the session.) One student wrote:

This exercise served multiple purposes. The first part, the opening statement, was an exercise in how to concisely get a point across as the statement was supposed to be no more than a minute. Since it was to be read aloud, it also had to serve as something that could easily be understood orally rather than if it was just on the page. Anything that could possibly serve as a sound bite would be a bonus. The second part, the questions, was an exercise in formulating intelligent sounding questions about a subject you probably know very little about. It's very important to make sure the member of Congress looks good and so they need to at least look like they know what they're talking about, and this is best conveyed through the intelligence of the questions they ask (Schutt 2011).

Although they did not get the same thrill that I got when Hillary Clinton's deputy called Mr. Ellison's office to find out ahead of time what the Congressman was likely to ask in a hearing on foreign aid, my students did learn that the success of a witness is related to an effective working relationship with political staff. They also internalized "basics" that revealed some surprisingly large gaps in general awareness about how Congress works. For example, as we were picking roles for the hearing, one student commented that "it wasn't fair" that Republicans and Democrats did nothave a 50-5o distribution in committee assignments. That was indeed a teachable moment about the consequences of elections. "Turns?" Toby Ziegler says in an episode of West Wing, "There are no turns."

At one point during my work in Congress, as I was running relays between the Longworth House Office Building and the Capitol and offering background and opinion on upcoming issues, I thought about a "walk and talk" final oral exam for my politics students. Back on campus, I explained to students that their final assignment was to research an issue that would be a difficult vote for their congressional member and then, in the time that it took us to cruise the halls of Earlham's social science building at a rapid clip, tell me (as the member's stand-in) how to vote and why. Figuring out an issue that would indeed be difficult for the member was the first hurdle. Students, having the earlier experience of compiling a dossier, had some resources to use. One enterprising student from Nicaragua was particularly interested in an upcoming vote on the Colombia Free Trade agreement. He 
discerned that members of the Congressional Caucus on Colombia were likely to favor the agreement. He knew that the Service Employees International Union (SEIU) was much opposed. Scrolling through an overlap list of members who were in both the Columbia Caucus and the Progressive Caucus, he located a member who had received significant campaign contributions from the SEIU. He concluded that the vote on the Free Trade Agreement would be particularly difficult for her.

All students wrote up a one-page decision memo (see description and sample in the attached syllabus) that included background on the difficult issue that they had identified, reasons to vote in favor of the bill they had identified, reasons to vote against, and the rationale for their opinion on which way to vote. Then they chased me as I hightailed it down the hall, giving thanks for the voice recorder in my smartphone, which provided the technological support for evaluating the exercise. They sweated about being succinct, they worried about walking and talking at the same time, and they also learned that rapid-fire judgments are required in Congress and these are judgments that matter. Our on-campus course work was supplemented by attending a town hall meeting with Mike Pence (R-IN) who represents Earlham's district, and by a visit from Allen Paul, a State Senator in the Indiana legislature. We were also able to travel to Washington, DC to participate in a lobby training weekend coordinated by the Friends Committee on National Legislation, where students heard from Congressman Jim McDermott (D-WA), and we planned meetings with representatives from students' home districts. Collectively we talked about the purpose of meeting with members and their staffs when, as a group, we had diverse political agendas. Students had an opportunity to compare the various ways in which different members presented themselves to their constituents and the use they made of their staffs.

\section{CONCLUSION}

Ultimately, the course turned out to be a rich experience for all those involved-including students in other classes who participated in the letter-writing and mock hearing exercises. This was true both for the students with better preparation, such as the student from Nicaragua who pursued and obtained an internship with the Organization for American States using his course portfolio, and for students who had never been outside of Indiana prior to the Washington field trip (and wondered, in fact, why non-US citizens would be interested in a course on the US Congress).

What conclusions might be drawn from this experience? I share Simeone's (2011) belief, "Just as people who follow Miss Manners' advice to write 'thank you' notes discover that they are more appreciative, so we hope our students who practice engagement will discover with time that they believe they ought to do it." Feedback from students suggests that these students are more likely to pursue governmental internships than they were beforehand and the internships that they secured in months following are giving them an opportunity to prove their developing skills. And-I believe-to doing the work of Congress. As a teacher, I enjoyed an experience that was not only more interactive, but felt more passionate, more "real" as I did my best to convey what I had learned in the agora of American politics. Although they did not acknowledge so immediately, I believe that the students in the course started to replace some cynicism with healthy questions about how to do democracy well. In doing so, the course fulfilled the Project Pericles goals (see table 1). If it is true that one never really learns a subject until you teach it, it also seemed to be true that I never really understood the work of good citizenship myself until I had been at the receiving end of constituent meetings for a year. In the Fellowship year I acquired tools for building my students' capacity to counter cynicism with engaged action. The Congressional Fellowship transformed what my students and I imagined politics to be and how we conceive of participating in the process.

\section{NOTES}

I would like to thank Jeff Biggs and Katrina Gamble for their comments. I would also like to thank my colleagues in Keith Ellison's office, all of the Fellows in the 2009-10 APSA CFP class, and my students in the Spring 2011 edition of Legislative Toolkit at Earlham for shared purpose and camaraderie.

1. An "ask" is a request for legislative action.

\section{REFERENCES}

American Political Science Association. 2011. "2011 APSA Teaching and Learning Conference Track Summaries.” PS: Political Science \& Politics 44 (3): 664-66.

Bicknell, John, and David Meyers. 2011. CQ's Politics in America 2010: The 112th Congress. Washington, DC: CQ Press.

Block, Melissa. 2010, 2 September. "Theodore Parker and the 'Moral Universe'," All Things Considered (http://www.npr.org/templates/story/story.php? storyId $=129609461$ ) (Accessed July 13, 2011).

“Congressional Favorability at 24-Year-Low," 2009, 2 September $\langle$ http://peoplepress.org/files/legacy-pdf/539.pdf Washington, DC (Accessed July 13, 2011).

Gillespie, Andra, and Melissa R. Michelson. 2011. "Participant Observation and the Political Scientist: Possibilities, Priorities, and Practicalities.” PS: Political Science and Politics 44 (2): 261-66.

Granizo, Eduardo. 2011. Final Portfolio for Politics 300, Department of Politics, Earlham College, Richmond, Indiana. Personal communication with author.

Hall, Conor D. 2011. Final Portfolio for Politics 30o, Department of Politics, Earlham College, Richmond, Indiana. Personal communication with author.

King, Martin Luther, Jr. 1989. Where Do We Go from Here: Chaos or Community? Boston: Beacon Press.

Liazos, Ariane, and Jan Liss. 2009, August. "Civic Engagement in the Classroom: Strategies for Incorporating Education for Civic and Social Responsibility in the Undergraduate Curriculum," in A Project Pericles White Paper 〈http:// www.projectpericles.org/projectpericles/attachment_8.pdf) (Accessed 13 July 2011).

Longo, Nicholas P., and Ross Meyer. 2006, May. "College Students and Politics: A Literature Review," Kettering Foundation, CIRCLE Working Paper $46\langle$ http:// www.civicyouth.org/PopUps/WorkingPapers/WP46LongoMeyer.pdf) (Accessed 17 May 2011).

McDonald, Michael K. Forthcoming. "Internships, Service Learning, and Study Abroad: Helping Students Integrate Learning Across Multiple Experiences.” In From Service-Learning to Civic and Political Engagement, eds. Alison Rios Millett McCartney, Elizabeth A. Bennion, and Dick Simpson. Washington, DC: American Political Science Association: Washington, DC.

Pennock, Andrew. 2011. "The Case for Using Policy Writing in Undergraduate Political Science Courses.” PS: Political Science \& Politics 44 (1): 141-46.

Pew Research Center. 2009. "Congressional Favorability at 24-Year Low," September 2. http://people-press.org/files/legacy-pdf/539.pdf (Accessed July 13, 2011).

Schutt, David. 2011. Final Portfolio for Politics 3oo, Department of Politics, Earlham College, Richmond, Indiana. Personal communication with author.

Simeone, James. 2011. "Assessing the Quality of Citizenship: Do Project Pedagogies Make a Difference?" APSA Teaching and Learning Conference. Albuquerque, NM. February 11-13.

Smith, Elizabeth T., and Mark Boyer. 1996. "Designing In-Class Simulations.” PS Political Science \& Politics 29 (4): 690-94.

Smith, Eric R.A.N. 2001. "SIMCONG: A Simulation of the U.S. House of Representatives." Classroom Instruction Manual, Department of Political Science, University of California, Santa Barbara. Personal communication with author

Strand, Mark, Michael S. Johnson, and Jerome F. Climer. 2008. Surviving Inside Congress: A Guide for Prospective, New and not-So-New Congressional Staff and a Guided Tour for Those Who Just Want to Learn How It All Works. Alexandria, VA: The Congressional Institute.

The Center on Congress at Indiana University. 2007. The Virtual Congress 〈http:// www.tpscongress.org/teachers/activity.php?id=12〉 (Accessed July 13, 2011).

"What is a Social Entrepreneur?" 〈http://www.ashoka.org/social_entrepreneur (Accessed July 13, 2011) 


\section{APPENDIX I}

Professor B. Welling Hall

Office: LBC 234

wellingh@earlham.edu

765-983-1208
Tuesday, Thursday: 1:00

Class Room: LBC 124 and Lilly Lab

Optional Field Trip: 3/18-3/21

\section{Politics 300: Congressional Staff Toolkit}

\section{Course Description:}

This course is designed to prepare students for civic engagement by helping students translate how the work that they do in the liberal arts classroom is directly related to effective engagement in the legislative process. Students majoring in Politics, International Studies, and Peace Studies are especially welcome, although students with any liberal arts major may find that the skills and methods taught in the course will be useful preparation for internships and jobs in government or as lobbyists.

Over the semester we can anticipate some visits from representatives and staffers of elected officials. In addition to lobby training, the optional field trip will include some direct communication with elected officials in Washington, DC. (or, more likely, members of their staffs).

Although there is not an explicit prerequisite other than one introductory course in Politics, students must demonstrate competence in (1) fundamentals of American government, and (2) advanced English stylistics. All students must ace an English grammar and punctuation quiz by the time that early semester reports are due.

Course Objectives:

- Understand the daily work of a Congressional office.

- Learn the legislative priorities and communication styles of members of Congress.

- Develop a portfolio of writing samples that can be used in the process of securing government internships in Washington, DC or elsewhere.

\section{Course Materials:}

Required text: Strand, Johnson, Climer, Surviving Inside Congress (Congressional Institute, 2010)

Most course materials (not Surviving Inside Congress) will be available online or in the reference section of Lilly.

\section{Evaluation:}

This course will emphasize group drafting, redrafting, and editing as part of the process of electoral politics. At the end of the course, students will submit a final portfolio and will be graded based on a rubric such as the one attached below. Final evaluation in the course will also include some peer evaluation.

One anticipated special project will be doing the work of organizing a hearing and putting together a briefing book and preparing members of Congress to question witnesses.

One project in this course will be a rapid-fire oral quiz in which you will need to assist your boss (in this case, your professor) in making an immediate decision. 


\begin{tabular}{|c|c|c|c|c|c|}
\hline & 1 & 2 & 3 & 4 & Total \\
\hline Organization & $\begin{array}{l}\text { Individual assignments } \\
\text { cannot be understood } \\
\text { because there is no clear } \\
\text { sequence of thought. }\end{array}$ & $\begin{array}{l}\text { Assignments are difficult } \\
\text { to follow because themes } \\
\text { and topics jump around. }\end{array}$ & $\begin{array}{l}\text { Material is presented in } \\
\text { logical sequence which } \\
\text { reader can follow. }\end{array}$ & $\begin{array}{l}\text { Material is presented in a } \\
\text { logical, engaging } \\
\text { sequence which reader } \\
\text { can follow easily. }\end{array}$ & \\
\hline Mastery of Material & $\begin{array}{l}\text { Student does not demon- } \\
\text { strate grasp of primary } \\
\text { concepts in the course. }\end{array}$ & $\begin{array}{l}\text { Student identifies main } \\
\text { points in the reading for } \\
\text { the course. }\end{array}$ & $\begin{array}{l}\text { Student is at ease with } \\
\text { several course concepts } \\
\text { and provides some con- } \\
\text { text. }\end{array}$ & $\begin{array}{l}\text { Student demonstrates } \\
\text { familiarity with the con- } \\
\text { ceptual scheme of course } \\
\text { authors, including some } \\
\text { nuances. }\end{array}$ & \\
\hline Synthetic Thinking & $\begin{array}{l}\text { Assignments make no } \\
\text { connection from this } \\
\text { course to other readings } \\
\text { or events. }\end{array}$ & $\begin{array}{l}\text { Assignments make } \\
\text { generic, unelaborated } \\
\text { connection from this } \\
\text { course to unspecified } \\
\text { readings or events. }\end{array}$ & $\begin{array}{l}\text { Assignments make } \\
\text { unelaborated connection } \\
\text { from this course to spe- } \\
\text { cific readings or events. }\end{array}$ & $\begin{array}{l}\text { Assignments make origi- } \\
\text { nal, insightful links from } \\
\text { this course to other read- } \\
\text { ings or events. }\end{array}$ & \\
\hline Mechanics & $\begin{array}{l}\text { Assignments have four or } \\
\text { more spelling errors } \\
\text { and/or grammatical } \\
\text { errors. }\end{array}$ & $\begin{array}{l}\text { Assignments have three } \\
\text { misspellings and/or gram- } \\
\text { matical errors. }\end{array}$ & $\begin{array}{l}\text { Assignments have no } \\
\text { more than two misspell- } \\
\text { ings and/or grammatical } \\
\text { errors. }\end{array}$ & $\begin{array}{l}\text { Assignments have no } \\
\text { more than one misspell- } \\
\text { ing or grammatical error. }\end{array}$ & \\
\hline Professionalism* & $\begin{array}{l}\text { Student's presentation is } \\
\text { sloppy, i.e. marked by a } \\
\text { lack of care, precision, or } \\
\text { respect. }\end{array}$ & $\begin{array}{l}\text { Student's presentation } \\
\text { tends to the sloppy side- } \\
\text { misses several elements } \\
\text { of professionalism. }\end{array}$ & $\begin{array}{l}\text { Student's presentation is } \\
\text { careful, precise, and } \\
\text { respectful. }\end{array}$ & $\begin{array}{l}\text { Student's presentation is } \\
\text { noteworthy in its degree } \\
\text { of professionalism. }\end{array}$ & \\
\hline
\end{tabular}

*For more ideas about what constitutes professionalism, see http://myopenuniversity.com/download/mou_pdf_artical/how_to_be_a_professional.pdf

Course Schedule: Anticipate Change! We will need to make some adjustments depending on when various elected officials and/or staff are willing and able to meet with us.

\begin{tabular}{|c|c|}
\hline \multirow[t]{2}{*}{ January 14} & Class Intro \\
\hline & Activities = quiz on fundamentals of US government, quiz on grammar and punctuation \\
\hline \multirow[t]{3}{*}{ January 18} & Introduction to the Daily Work of a Congressional Office-Lilly Lab \\
\hline & Read: Chapter One of Surviving in Congress: “In the Beginning” \\
\hline & Activities = group time putting together a presentation on individual member-Lilly Lab \\
\hline
\end{tabular}

January $21 \quad$ Meeting Our Members-Lilly Lab

Prepare: Representatives Andre Carson, Mike Pence, Betty McCollum, John Boehner; and Senators Richard Lugar and

Bernie Sanders

Activities $=$ putting together a schedule for a member of Congress

January 25 First Steps in a Congressional Office-LBC 124

Read: Chapter Two of SiC: "A Job or a Career?"

Update: What have our members been up to?

Activities = read through some files, what is the variety of issues that a member of Congress might have to confront?

\begin{tabular}{ll}
\hline January 28 & MODEL UN-NO CLASS \\
\hline February 1 & Day to Day Work with Constituents-Lilly Lab
\end{tabular}

Read: Chapter Three of SiC: "Who's Who?"

Update: What have our members been up to?

Activity: Research Answers for Letters to Constituents

Note: Steve Butler's sociology class, "Institutions and Inequality," will provide letters for us to write responses.

February $4 \quad$ Mail, mail, mail-Lilly Lab

Update: What have our members been up to?

Activity: Writing Letters to Constituents \#2

February 8 Session with lobbyists from Friends Committee on National Legislation and Bread for the World

February 11 NO CLASS 


\begin{tabular}{|c|c|}
\hline February 15 & $\begin{array}{l}\text { The Genesis of a Law-LBC } 124 \\
\text { Read: Chapter Five of SiC: "The Genesis of a Law" } \\
\text { Update: What have our members been up to? } \\
\text { Lecture: Reform of the JJDPA }\end{array}$ \\
\hline February 18 & NO CLASS (Spring Break) \\
\hline February 22 & Attend Town Hall with Representative Mike Pence (See Handout I attached) \\
\hline February 25 & VISIT FROM INDIANA STATE HOUSE SENATOR ALLEN PAUL (See attached handout) \\
\hline March 1 & $\begin{array}{l}\text { Talking Points-Lilly Lab } \\
\text { Update: What have observed about the behavior of legislators? } \\
\text { Read (Moodle): CRS backgrounder on speech writing. Also links to Talking Points } \\
\text { Activity: Research for Talking Points }\end{array}$ \\
\hline March 4 & $\begin{array}{l}\text { Non-Binding Resolutions - Lilly Lab } \\
\text { Update: What have our members been up to? } \\
\text { Activity: Practice Writing a Non-Binding Resolution }\end{array}$ \\
\hline March 8 & $\begin{array}{l}\text { Introducing a Bill-Lilly Lab } \\
\text { Read: Chapter Six in SiC: "Formal Introductions" and CRS backgrounder on speech writing } \\
\text { Update: What have our members been up to? } \\
\text { Activity: Write a one-minute on a bill }\end{array}$ \\
\hline March 11 & $\begin{array}{l}\text { Working with the Press-LBC } 124 \\
\text { Read: Chapter Nine in SiC: “Keys to Communication" } \\
\text { Update: What have our members been up to? } \\
\text { Activity: Write a Press Release }\end{array}$ \\
\hline March 15-17 & SPRING BREAK \\
\hline March 18-22 & FIELD TRIP to FRIENDS COMMITTEE ON NATIONAL LEGISLATION YOUNG ADULT LOBBY WEEKEND \\
\hline March 25 & NO CLASS \\
\hline March 29 & $\begin{array}{l}\text { Communications Strategy - Lilly Lab } \\
\text { Read: Chapter Ten in SiC: "Strategic Communication" } \\
\text { Update: What have our members been up to? } \\
\text { Activity: Evaluate congressional websites }\end{array}$ \\
\hline April 1 & $\begin{array}{l}\text { Making Change Happen-Lilly Lab } \\
\text { Read: Chapter Twelve in SiC: “Leading Major Change" } \\
\text { Update: what have our members been up to? } \\
\text { Activity: Organizing a hearing. Students in the Global Energy Policy course will serve as our expert witnesses. }\end{array}$ \\
\hline April 5 & $\begin{array}{l}\text { Making Change Happen continued-Lilly Lab } \\
\text { Update: What have our members been up to? } \\
\text { Activity: Organizing a Hearing on Energy Policy continued }\end{array}$ \\
\hline April 8 & Holding a Hearing/Questions-LBC 124 \\
\hline April 12 & $\begin{array}{l}\text { The Role of Public Opinion-Lilly Lab } \\
\text { Read: Chapter Eleven in SiC: "Public Opinion and Public Judgment" } \\
\text { Update: what have our members been up to? } \\
\text { Activity: Talking Points again (controversial issue) }\end{array}$ \\
\hline April 15 & Drafting a Decision Memo on a Hot Topic (See attached Assignment) \\
\hline April 19 & Decision Memo on Hot Topic continued-Lilly Lab \\
\hline April 22, 26 & Work on Portfolios \\
\hline April 29 & Course Conclusion \\
\hline
\end{tabular}


Handout I: Observing a Member Interacting with Constituents

1. How does the member establish authority (location, occasion, words, props, etc.)?

2. How does the member establish a bond with audience?

3. How does the member position himself relative to the Legislative Body (DC or Indianapolis)?

4. What issues are important for the member?

5. How does the member or how do staff handle controversy?

6. How visible are staff?

Assignment I: Final Project for Legislative Toolkit

For your last assignment, prior to submitting the last, complete draft of your portfolio, you will talk with me about your decision memo.

The syllabus indicates:

"One project in this course will be a rapid-fire oral quiz in which you will need to assist your boss (in this case, your professor) in making an immediate decision."

Most of these conversations will happen during our final class session on Friday, April 29 between 1:00 and 2:30. Some will occur later on Friday afternoon.

Your job will be to tell me how to vote on a bill that you have identified as a difficult vote. You will tell me how to vote as we walk on a roundtrip loop from my office through the corridors of LBC and back again. This is directly analogous to telling a member of Congress about an issue and how to vote while in the corridors of Congress.

This conversation will be based on a decision memo that you have written on this topic. See a successful student memo below:

\title{
Sample Student Decision Memo
}

\author{
To: Karen Bass (D, CC-33)
}

From: Eduardo Granizo

Date: April 29, 2011

Re: Position on the U.S.-Colombia Free Trade Agreement

The Congress has delayed for more than four years the approval of the Colombia FTA. One of the reasons why it has not been approved concerns the labor and human rights violations within the Afro-Colombian population. Recently, several members from the Republican Party and President Obama have issued statements on the need to approve this FTA.

Timing: The approval of this FTA has been delayed exactly by 1620 days as indicated in the Ways and Means committee. This has represented a loss of $\$ 3.5$ billion in concept of tariffs imposed on U.S. exports to Colombia since the signing of the FTA.

Yes President Obama issued a statement on April 7, 2011, in which he encouraged Congress to approve the Colombia Free Trade Agreement as soon as possible. His announcement also reported on advances made in addressing labor rights issues. These have been a bone of contention in the past between those who are for and those who are against passing this agreement. On the Congress side, Chairman Dave Camp (R-MI) and Democratic Whip Steny Hoyer (D-MD) led a bipartisan mission to Colombia in order to evaluate the continuing work to carry out the Action Plan Related to Labor Rights to which Colombia and the Administration agreed on April 7.

Eduardo: A "Yes" vote is necessary especially in the context, in which a number of Republicans have shown support for passing this agreement, especially those from the Ways and Means committee. It is important to take this opportunity to engage in bipartisan cooperation in order to approve this treaty. Both President Obama and the Republicans in Ways and Means committee are actively pursuing the approval of this FTA 
No The Service Employees International Union (SEIU), the fastest-growing union in North America, with a membership of over 2.2 million members issued a statement immediately after Obama's Free-Trade Deal with Colombia Statement, in which they flatly opposed the U.S.-Colombia Free Trade Agreement. For them, " $[t]$ his agreement is another example of failed trade policies that have resulted in the loss of millions of U.S. jobs." In citing The Economic Policy Institute, they express that this agreement will result in the loss of 55,000 jobs in the U.S. - the last thing our economy needs. Concerning your district, SEIU was your third largest single contributor during your campaign in last year's election. During the 2010 campaign, SEIU spent nearly $\$ 15.8$ million on advertisements and other communications known as independent expenditures that overtly advocated for or against federal political candidates, with Democrats benefiting from almost all of them.

Eduardo: While the SEIU has concerns about the labor rights abuses, there is an initiative to work towards improving this issue. Voting 'No' is more costly, given that a number of Democratic and Republicans have reconsidered their approach on this topic and have decided to support it.

Positions among other Democrats who are also funded by SEIU

Judy Chu (D-CA)-Not Announced Yet

Timothy Bishop (D-NY)-Not Announced Yet

Mark Critz (D-PA)-Not Announced Yet

Ted Deutch (D-FL)-Not Announced Yet

Jerry McNerney (D-CA)-Not Announced Yet

Bill Owens (D-NY)-Not Announced Yet

\section{Resolutions that have been put forward in both Houses in Congress}

$112^{\text {th }}$ Congress House Resolution 86-Recognizing the importance of trade to the United States economy and the importance of passing free trade agreements with Colombia, South Korea, and Panama.

Sponsor: Rep Frelinghuysen, Rodney P. [NJ-11]

Co-Sponsor: 4

Similarly $112^{\text {th }}$ Congress Senate Resolution 20-A resolution expressing the sense of the Senate that the United States should immediately approve the United States-Korea Free Trade Agreement, the United States-Colombia Trade Promotion Agreement, and the United StatesPanama Trade Promotion Agreement.

Sponsor: Senator Johanns, Mike

Co-Sponsor: 18

\section{Sources}

Bass, Karen-CA 33 ${ }^{\text {rd }}$ District Congresswoman Website. 〈http://karenbass.house.gov/〉

Service Employees International Union. Statement on U.S.-Colombia Free Trade Agreement. April, 8, 2011. (http://www.seiu.org/2011/04/ us-colombia-free-trade-agreement.php〉

Open Secrets Organization. 〈http://www.opensecrets.org/orgs/summary.php?id=D000000077〉

Ways and Means Committee. 〈http://waysandmeans.house.gov/News/DocumentSingle.aspx?DocumentID=234512〉

White House Website. Overview of the Colombia Trade Agreement. (http://www.whitehouse.gov/sites/default/files/rss_viewer/

OverviewoftheColombiaTradeAgreement.pdf) 


\section{APPENDIX II}

Congressional Toolkit

Assignment \#2

\section{Schedule a member's meetings and activities for a week}

Many Congressional schedulers are in their twenties. This is a good example of an entry-level task in Congress-and a critical job which performs an essential gate-keeping function for a busy office.

Your job: with your teammates look at the meeting requests and required activities in the list below and put them into a weekly calendar Sunday-Saturday in half hour increments between 8:00 a.m. and 8:00 p.m. These are items that member or CoS says that member must attend to personally, at least by making a brief appearance.

Note: Your Boss wants to be in the District Friday-Monday. Build in 4 hours travel time each way (see below). Meetings that are not specified as District meetings take place in DC.

Reception with Advocacy Group

Annual DC Constituent Day on Capitol Hill

Breakfast with Administration Official

Breakfast with Visiting Head of State

Briefing Time with Legislative Assistants

Brunch Event

Call Time (reaching out to donors and funders)

Caucus Lunch Meeting

Caucus Meeting

Caucus Meeeting on Job Creation

Caucus Press Conference

Coffee with State Representative

Committee Hearing A

Committee Hearing B

Daughter's Dance recital

Party Caucus Meeting on Iran

District staff meeting

Family Time

Floor Time

Interview with Local Radio Personality

Introduce celebrity to fellow member

Invitation to Give Keynote at State Police

Convention

Invited to speak on Sunday morning talk show

Invited to Speak to Public Event A

Invited to Speak to Public Event B

Meet with White House on Legislative Issue

Meeting about Housing and Urban Development with Speaker

Meeting with Ambassador

Meeting with Assistant Sec'y of State

Meeting with Breast Cancer Coalition

Meeting with Director of Center that is giving you an award on Thursday evening

Meeting with Crisis Management Group

$\begin{array}{ll}2 \text { hours } & \text { Tuesday evening } 7 \mathrm{pm} \\ 1 \text { hour } & \text { Friday } 10 \text { am } \\ 1 \text { hour } & \text { Tuesday morning } 8 \text { am } \\ 1 \text { hour } & \text { Wednesday } 8 \text { am } \\ 1 \text { hour } & \text { Before significant votes } \\ 1 \text { hour } & \text { Must be noon on Sunday, } 1 \text { hour from home in District } \\ 5 \text { hours } & 1 \text { hour daily }- \text { need to call from Party HQ or home (not from } \\ & \quad \text { Congress) } 20 \text { minute walk each way } \\ 2 \text { hours } & \text { Wednesday noon } \\ 1 \text { hour } & \text { Wednesday } 5 \text { pm } \\ 2 \text { hours } & \text { Tuesday } 11 \\ 1 \text { hour } & \text { Tuesday morning } 11 \\ 1 \text { hour } & \text { in District } \\ 3 \text { hours } & \text { Tuesday morning } 11-2 \\ 3 \text { hours } & \text { Thursday } 9-12 \\ 1 \text { hour } & 6 \text { pm on Sunday } \\ 1 \text { hour } & \text { Wednesday } 4 \text { pm } \\ 1 \text { hour } & \text { in District } \\ 6 \text { hours } & \text { only on weekends when in district } \\ \text { As needed } & \text { Votes and debate can be called any time during the day on } \\ & \text { Tuesday, Wednesday, or Thursday see schedule in Congressional } \\ 30 \text { minutes } & \text { Institute book } \\ 30 \text { minutes } & \text { During regular business hours in DC } \\ 30 \text { minutes } & \text { Saturday } 7 \text { pm } \\ & \\ & \end{array}$

2 hours

Event runs from 10 to 12 on Thursday

2 hours Wednesday evening $6-8 \mathrm{pm}$

1 hour Thursday 10 am (will need 30 minutes travel time each way

1 hour Wednesday 11 am

30 minutes Thursday 
Meeting with Donor in DC

Meeting with Donor in District

Meeting with Constituent Organization

Meeting with Constituent Organization

Meeting with Local Student who won National Award

Meeting with Constituent Organization

Meeting with Union A Representatives

Meeting with Union B Representatives

Meeting with University Development Director

Personal Time

Reception with Constituent Group that is Making Award

Reserve time for dinner with elder statesman

Son's Graduation Party

Speak about findings of CoDel

Speak at local High School

Speak at Youth Center in District

Speak at Youth Convention in District

Speak to Senior Community Center

Speaker's Dinner Reception on Public Policy

Time with Chief of Staff

Time with Legislative Director

Travel between District and DC
30 minutes

30 minutes

15 minutes

15 minutes

15 minutes In DC

30 minutes

1 hour

Friday 5 pm in District

15 minutes

3 hours

2 hours

1 hour

1 hour

1 hour

1 hour

1 hour

2 hours

1 hour

1 hour

8 hours
Only on weekends when in district

Thursday evening 7 pm 30 minute walk from office

in DC

Saturday 6-9 pm

Event at noon on Thursday

1 hour travel time from home office

Friday in district

Wednesday evening 7-9 pm

Needs to happen every day in DC

Needs to happen early in DC work week

Mondays and Thursdays (4 hours each way) 


\section{CAMBRIDGE}

\section{JOURNALS}

\section{Published on behalf of the University of Notre Dame}
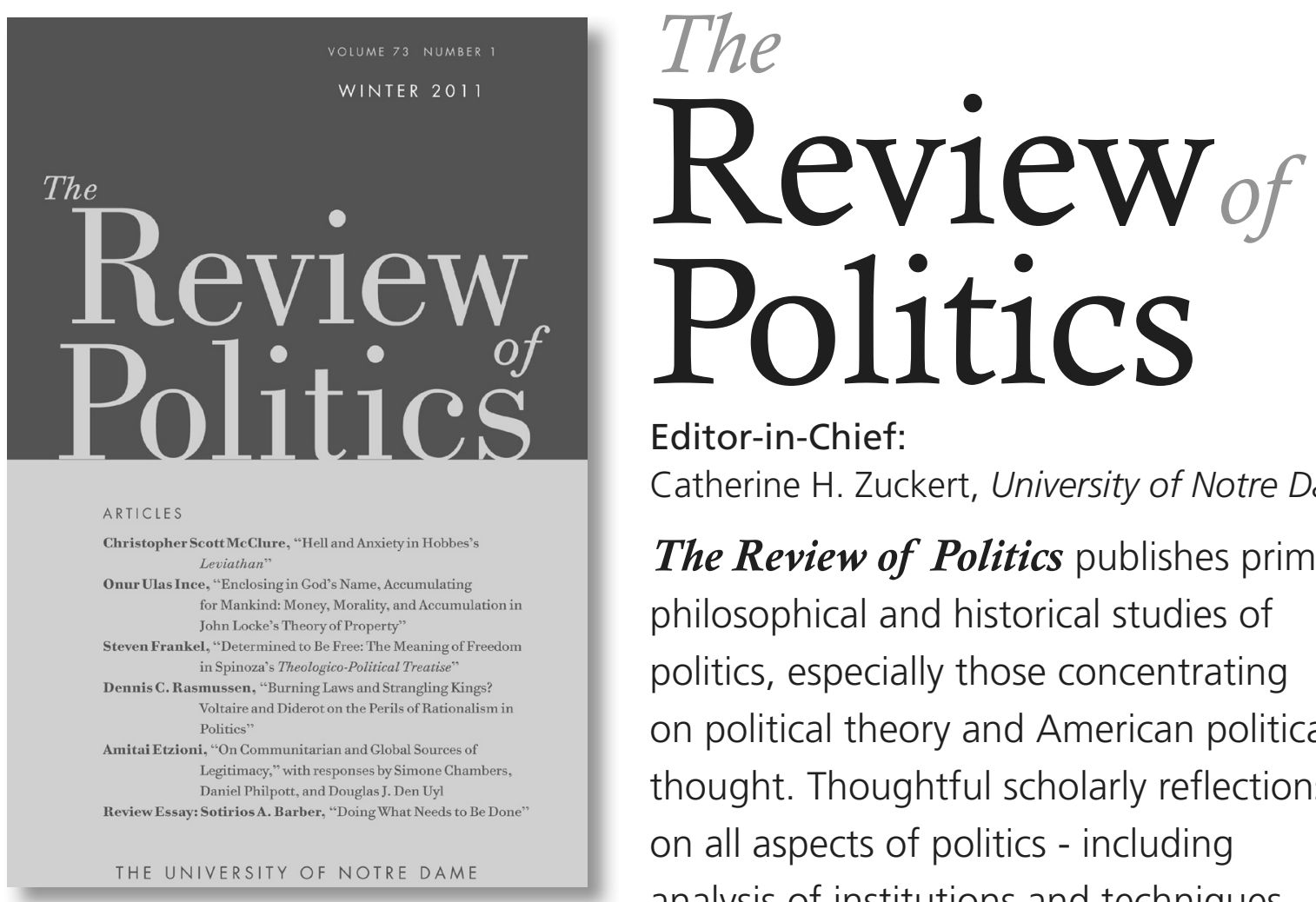

Editor-in-Chief:

Catherine H. Zuckert, University of Notre Dame

The Review of Politics publishes primarily philosophical and historical studies of politics, especially those concentrating on political theory and American political thought. Thoughtful scholarly reflections on all aspects of politics - including analysis of institutions and techniques, analysis of literary reflections on politics, political interpretations of literary works, and constitutional theory and analysis - are also welcome. Some of the first essays advocating "realism" were published in The Review, as well as articles from its opponents in international relations; both perspectives are accepted parts of the journal's coverage.

FRE E email alerts.

Keep up-to-date with new material. Sign up at: journals.cambridge.org/rop-alerts

Recommend The Review of Politics directly from its homepage FRE online access for you when your library subscribes.

\section{journals.cambridge.org/rop}

